\title{
ASPEK HUKUM PEMBERIAN HPL ATAS BIDANG TANAH YANG TELAH DIKUASAI, DIDUDUKI ATAU DIGARAP OLEH WARGA
}

\author{
Felix Kurniawan \\ Universitas Surabaya
}

\begin{abstract}
ABSTRAK
Artikel ini membahas akibat hukum pemberian Hak Pengelolaan (HPL) atas bidang tanah yang telah dikuasai, diduduki atau digarap oleh warga. Negara sebagai pemegang kekuasaan tertinggi atas tanah, kekuasaan tersebut meliputi mengatur dan menyelenggarakan peruntukan, penggunaan, persediaan dan pemeliharaan bumi, air dan ruang angkasa tersebut; menentukan dan mengatur hubungan-hubungan hukum antara orang-orang dengan bumi, air dan ruang angkasa; menentukan dan mengatur hubungan-hubungan hukum antara orangorang dan perbuatan-perbuatan hukum yang mengenai bumi, air dan ruang angkasa. Atas dasar hak menguasai dari negara tersebut ditentukan adanya macam-macam hak atas permukaan bumi, yang disebut tanah, yang dapat diberikan kepada dan dipunyai oleh orang-orang baik sendiri maupun bersamasama dengan orang lain serta badan-badan hukum. Kekuasaan negara atas tanah yang tidak dipunyai dengan sesuatu hak oleh seseorang atau pihak lainnya adalah lebih luas dan penuh.Keputusan Menteri Negara Agraria/Kepala Badan Pertanahan Nasional menerbitkan Keputusan No. 53/ HPL/BPN/1997 tentang Pemberian HPL atas Nama Pemerintah Kotamadya Daerah Tingkat II Surabaya, padahal bidang tanah tersebut telah dikuasai oleh warga cacat hukum.
\end{abstract}

Kata Kunci: aspek hukum, Hak Pengelolaan, Hak Menguasai Negara

\begin{abstract}
This article discusses the legal consequences of granting Management Rights (HPL) on land that has been controlled, occupied or cultivated by residents. The state as the highest holder of power over land, that power includes regulating and carrying out the designation, use, supply and maintenance of the earth, water and space; determine and regulate legal relations between people and earth, water and space; determine and regulate legal relations between people and legal actions concerning earth, water and space. On the basis of the state's right to control, there are various kinds of rights to the surface of the earth, called land, which can be given to and owned by people both alone and together with other people and legal entities. State power over land that is not owned by a person or other party's rights is wider and fuller. Decree of the State Minister for Agrarian Affairs / Head of the National Land Agency issues Decree No. 53 / HPL / BPN / 1997 concerning the Provision of HPL on behalf of the Surabaya Level II Municipal Government, even though the land has been controlled, occupied or cultivated by residents who have no legal basis.
\end{abstract}

Keywords: legal aspect, Management Rights on Land, the right to control by the state 


\section{A. PENDAHULUAN}

Negara Republik Indonesia yang susunan kehidupan rakyatnya, termasuk perekonomiannya, terutama masih bercorak agraris, bumi, air dan ruang angkasa, sebagai karunia Tuhan Yang Maha Esa mempunyai fungsi yang amat penting untuk membangun masyarakat yang adil dan makmur. Hukum agraria yang masih berlaku sekarang ini sebagian tersusun berdasarkan tujuan dan sendi-sendi dari pemerintahan jajahan dan sebagian dipengaruhi olehnya, hingga bertentangan dengan kepentingan rakyat dan negara di dalam menyelesaikan revolusi nasional sekarang ini serta pembangunan semesta.

Tanah menurut Boedi Harsono dipakai dalam arti yuridis, sebagai suatu pengertian yang telah diberi batasan resmi oleh UUPA, ${ }^{1}$ dalam Penjelasan Pasal 4 UUPA dinyatakan bahwa "atas dasar hak menguasai dari negara ... ditentukan adanya macam-macam hak atas permukaan bumi, yang disebut tanah, yang dapat diberikan kepada dan dipunyai oleh orang-orang”. Tanah mempunyai arti yang penting karena tanah merupakan satu-satunya benda kekayaan yang meskipun mengalami keadaan yang bagaimanapun juga, tanah masih bersifat tetap dalam keadaannya, bahkan kadang-kadang malah lebih menguntungkan. Tanah karena faktanya merupakan tempat tinggal, memberikan penghidupan, merupakan tempat di mana warga masyarakat yang meninggal dikebumikan. ${ }^{2}$

Begitu kompleks fungsi tanah sehingga jika kondisi tanah di Indonesia yang dikenal subur tersebut dijadikan obyek negara asing untuk dapat menguasai bumi Indonesia melalui cara-cara penjajahan misalnya Belanda, Jepang, Portugis dan lainnya. Kolonialisme berusaha agar tanah dikuasai oleh penjajah tersebut, sehingga pengaturan mengenai pemanfaatan tanah juga harus tunduk pada aturan pemerintah penjajahan tersebut, sehingga di dalam negara terjadi dualisme hukum agraria, yaitu hukum agraria kolonial dan hukum agraria nasional.

1 Boedi Harsono, Hukum Agraria Indonesia, Sejarah Pembentukan Undang-undang Pokok Agraria, Isi dan Pelaksanaannya, Djambatan, Edisi Revisi, Jakarta, 2007, hlm. 18.

${ }^{2}$ Surojo Wignjodipuro, Pengantar dan Asas-asas Hukum Adat, Sumur Bandung, Jakarta, 1982, hlm. 197. 
Diundangkannya UUPA, yang diharapkan adanya suatu unifikasi hukum pertanahan di Indonesia, dari hukum tanah Pemerintah Hindia Belanda dengan hukum tanah untuk pribumi, dengan keharusan untuk melakukan alih status atau konversi terutama tanah hak barat (eigendom). Dualisme dalam Hukum Tanah bukan disebabkan karena para pemegang hak atas tanah berbeda hukum perdatanya, melainkan karena perbedaan hukum yang berlaku terhadap tanahnya. ${ }^{3}$ Tanah dalam hukum Indonesia mempunyai status atau kedudukan hukum sendiri, terlepas dari status hukum subyek yang mempunyainya. Hal ini berarti bahwa yang menentukan hukumnya bukan subyek atau orang yang dapat menguasai tanah tersebut, melainkan perbedaan hukum yang berlaku terhadap tanahnya atau obyek dari perbuatan hukumnya.

Dualisme hukum pertanahan yaitu adanya tanah dengan hak barat, seperti hak Eigendom, hak erfpacht, hak opstal, yang disebut tanah-tanah hak barat atau tanah-tanah Eropa. Ada tanah-tanah dengan hak-hak Indonesia, seperti tanahtanah dengan hak adat, yang disebut tanah hak adat. Selain itu ada tanah-tanah dengan hak-hak ciptaan Pemerintah Hindia Belanda seperti hak agrarisch Eigendom, landerijen bezitrecht. ${ }^{4}$ Hukum Barat atas tanah bersifat individualistik, maksudnya bahwa hukum tanah berpangkal dan berpusat pada hak individu atas tanah yang bersifat pribadi semata-mata.

Hukum agraria tersebut mempunyai sifat dualisme, dengan berlakunya hukum adat disamping hukum agraria yang didasarkan atas hukum barat, yang bagi rakyat asli hukum agraria penjajahan itu tidak menjamin kepastian hukum demikian bunyi Konsideran Bagian Menimbang UUPA. Hukum Barat kurang memberikan jaminan bagi hukum agraria, karena itu perlu adanya suatu dasar kenasionalan sebagaimana dimaksud dalam Penjelasan Umum bagian II. Pertamatama kenasionalan itu diletakkan dalam Pasal 1 ayat 1, yang menyatakan, bahwa: "Seluruh wilayah Indonsia adalah kesatuan tanah-air dari seluruh rakyat Indonesia, yang bersatu sebagai bangsa Indonesia" dan Pasal 1 ayat 2 yang berbunyi bahwa: "Seluruh bumi, air dan ruang angkasa, termasuk kekayaan alam

${ }^{3}$ Boedi Harsono, Hukum Agraria Indonesia Sejarah Pembentukan Undang-undang Pokok Agraria, Isi dan Pelaksanaannya, Djambatan, Jakarta, 1999, hlm. 53.

${ }^{4}$ Ibid. 
yang terkandung di dalamnya dalam wilayah Republik Indonesia sebagai karunia tuhan Yang Maha Esa, adalah bumi, air dan ruang angkasa bangsa Indonesia dan merupakan kekayaan nasional'.Ini berarti bahwa bumi, air dan ruang angkasa dalam wilayah Republik Indonesia yang kemerdekaannya diperjuangkan oleh bangsa sebagai keseluruhan, menjadi hak pula dari bangsa Indonesia, jadi tidak semata-mata menjadi hak dari para pemiliknya.

UUPA tidak menyebut tanah melainkan bumi, menurut Pasal 4 ayat (1) UUPA, bahwa "... permukaan bumi, yang disebut tanah, ...", yang berarti tanah merupakan bagian permukaan bumi. Bumi mempunyai arti penting bagi kehidupan, karena merupakan kekayaan nasional, oleh karena itu pada tingkatan tertinggi dikuasai oleh Negara sebagai organisasi kekuasaan seluruh rakyat sebagaimana Pasal 2 ayat (1) UUPA. Pengertian dikuasai oleh negara tersebut bukan berarti dimiliki, karena negara tidak diperkenankan memiliki tanah, melainkan hak menguasai dari Negara memberi wewenang untuk mengatur dan menyelenggarakan peruntukan, penggunaan, persediaan dan pemeliharaan bumi, air dan ruang angkasa tersebut; menentukan dan mengatur hubungan-hubungan hukum antara orang-orang dan perbuatan-perbuatan hukum yang mengenai bumi, air dan ruang angkasa. Namun ternyata masih ada bidang tanah dengan hak Barat di antaranya yakni hak eigendom, meskipun tidak dijumpai dalam UUPA, masih dijumpai dalam Pasal 1 Ketentuan-ketentuan Konversi, bahwa hak eigendom atas tanah mulai berlakunya Undang-undang ini sejak saat tersebut menjadi hak milik, kecuali jika yang mempunyai tidak memenuhi syarat sebagai yang tersebut dalam Pasal 21, dan belum dikonversi menjadi salah satu hak atas tanah sebagaimana diatur dalam Pasal 16 ayat (1) UUPA.

Perihal ketentuan konversi yang berasal dari hak Barat menurut Kepres No. 32 Tahun 1979. Pemberian batasan waktu untuk konversi hak atas tanah selama jangka waktu 20 (dua puluh) tahun adalah sebagaimana ditentukan dalam Pasal 1 Kepres No. 32 Tahun 1979 yang menentukan bahwa "tanah hak guna usaha, hak guna bangunan dan hak pakai asal konversi hak Barat, yang jangka waktunya akan berakhir selambat-lambatnya pada tanggal 24 September 1980, sebagaimana yang dimaksud dalam UUPA pada saat berakhirnya hak yang bersangkutan 
menjadi tanah yang dikuasai langsung oleh Negara”. Tanah-tanah tersebut ditata kembali penggunaan, penguasaan dan pemilikannya dengan memperhatikan masalah tata guna tanahnya, sumber daya alam dan lingkungan hidup, keadaan kebun dan penduduknya, rencana pembangunan di daerah, kepentingankepentingan bekas pemegang hak dan penggarap tanah/penghuni bangunan.

Ketentuan Pasal 16 ayat (1) UUPA mengenai macam-macam hak atas tanah tidak menyebut Hak Pengelolaan (selanjutnya disebut HPL) atas tanah. Meskipun demikian sebagaimana dikutip dari Penjelasan Umum UUPA, bahwa "Kekuasaan Negara atas tanah yang tidak dipunyai dengan sesuatu hak oleh seseorang atau pihak lainnya adalah lebih luas dan penuh". Hal ini berarti bahwa jika negara memberikan HPL, tentunya bidang tanah yang sebagian kekuasaan negara diserahkan berdasarkan HPL terbatas pada bidang tanah yang "tidak dipunyai dengan sesuatu hak oleh seseorang atau pihak lainnya", namun kenyataannya Pemerintah Kota memperoleh HPL berdasarkan Keputusan Menteri Negara Agraria/Kepala Badan Pertanahan Nasional menerbitkan Keputusan No. 53/ HPL/BPN/1997 tentang Pemberian HPL Atas Nama Pemerintah Kotamadya Daerah Tingkat II Surabaya, padahal bidang tanah tersebut telah dikuasai, diduduki atau digarap oleh warga. Hal yang dipermasalahkan adalah apa akibat hukum pemberian HPL atas bidang tanah yang telah dikuasai, diduduki atau digarap oleh warga.

\section{B. PEMBAHASAN}

A.P. Parlindungan menyatakan bahwa istilah HPL diambil dari bahasa belanda, yaitu Beheersrecht, yang diterjemahkan menjadi Hak Penguasaan. ${ }^{5}$ Maria S.W. Sumardjono juga sependapat dengan A.P. Parlindungan bahwa PP No. 8/1953 "mengatur tentang Hak Penguasaan sebagai terjemahan dari Beheersrechtatas tanah-tanah negara. ${ }^{6}$ PPNo. 8/1953 tentang Penguasaan Tanah-Tanah Negara

\footnotetext{
${ }^{5}$ A.P. Parlindungan, HPL Menurut Sistem Undang-Undang Pokok Agraria, Mandar Maju, Bandung, 1989, hlm.6.

${ }^{6}$ Maria S.W. Sumardjono, Kebijakan Pertanahan Antara regulasi dan Implementasi, Kompas, Jakarta, 2001, hlm.22.
} 
mengatur Hak Penguasaan atas tanah negara yang dikuasai oleh para jawatan dan daerah swatantra".

Istilah HPL baru muncul pada saat penerbitan Peraturan Menteri Agraria No. 9/1965 tentang pelaksanaan Konversi Hak Penguasaan atas Tanah Negara dan Kebijaksanaan Selanjutnya. Munculnya istilah tersebut terdapat pada Pasal 2 Permenag No.9 / 1965 yaitu : "Jika tanah Negara sebagai dimaksud pasal 1, selain dipergunakan untuk kepentingan instansi-instansi itu sendiri, dimaksudkan juga untuk dapat diberikan dengan sesuatu hak kepada pihak ketiga, maka hak penguasaan tersebut diatas dikonversi menjadi HPL sebagai dimaksud dalam pasal 5 dan 6, yang berlangsung selama tanah tersebut dipergunakan untuk keperluan itu oleh instansi yang bersangkutan". ${ }^{7}$

Dengan begitu, dapat diketahui bahwa HPL lahir dari konversi Hak Penguasaan atas tanah-tanah negara yang diberikan kepada pihak ketiga.HPL tidak lahir berdasarkan Undang-Undang maupun Peraturan Pemerintah, melainkan berdasarkan pada Peraturan Menteri tersebut di atas. Sehingga, sifat dari peraturan menteri tersebut berupa aturan kebijakan, bukan peraturan perundang-undangan. Menurut Boedi Harsono, Adanya HPL dalam Hukum Tanah Nasional disebut di dalam UUPA, tetapi tersirat dalam pernyataan dalam Penjelasan Umum, bahwa: "Dengan berpedoman pada tujuan yang disebutkan di atas, Negara dapat memberikan tanah yang demikian (yang dimaksud adalah tanah yang tidak dipunyai dengan sesuatu hak oleh seseorang atau pihak lain) kepada seseorang atau badan-badan dengan sesuatu hak menurut peruntukan dan keperluannya, misalnya dengan hak milik, hak guna usaha, hak guna bangunan, atau hak pakai atau memberikannya dalam pengelolaan kepada suatu Badan Penguasa (Departemen, Jawatan, atau Daerah Swatantra) untuk dipergunakan bagi pelaksanaan tugasnya masing-masing (Pasal 2 ayat 4)"8

Namun, meskipun HPL hanya diatur di Peraturan Menteri, tetapi kebijakan HPL memiliki kekuatan hukum yang mengikat dalam hal pelakasanaannya baik

${ }^{7}$ Peraturan Menteri Agraria No. 9 Tahun 1965 tentang Pelaksanaan Konversi Hak Penguasaan atas Tanah Negara dan Kebijaksanaan Selanjutnya.

${ }^{8}$ Boedi Harsono, Hukum Agraria Indonesia, Sejarah Pembentukan Undang-undang Pokok Agraria, Isi dan Pelaksanaannya, Jambatan, Jakarta, 2003, hlm. 276. 
bagi pemegang haknya yaitu departemen-departemen, direktorat-direktorat, Pemerintah Daerah maupun bagi pihak lain yang sengaja menggunakan HPL untuk kepentingan pihak tersebut.

Terkait dengan kebijakan pengaturan mengenaiHPL, merujuk pada Pasal 9 PMANo. 9/1965, setiap pemegang HPL wajib mendaftarkan haknya ke Kantor Pertanahan setempat. Selain pasal tersebut, kewajiban mendaftarkan HPL diatur dalam PMANo. 1/1966 tentang Pendaftaran Hak pakai dan HPL. Peraturan Menteri Agraria No. 1/1966 menetapkan bahwa selain Hak Milik, Hak Guna Usaha, Hak Guna Bangunan, maka harus pula didaftarkan menurut ketentuanketentuan Peraturan Pemerintah No.10/1961, yaitu :

a. Semua Hak Pakai, termasuk yang diperoleh departemen-departemen, jawatan-jawatan, dan daerah-daerah swatantra sebagai dimaksud dalam Peraturan Menteri Agraria No. 9/1965;

b. Semua HPL sebagai yang dimaksud dalam Peraturan Menteri Agraria No. 9/1965. ${ }^{9}$

Dalam perkembangannya, Pasal 9 PP No. 24/1997 tentang Pendaftaran Tanah menetapkan bahwa "HPL termasuk objek pendaftaran tanah, selain Hak Milik, Hak Guna Usaha, Hak Guna Bangunan, Hak Pakai, Tanah Wakaf, Hak Milik Atas Satuan Rumah Susun, Hak Tanggungan, dan tanah negara. ${ }^{10}$ Pendaftaran HPL dibuktikan dengan surat tanda bukti hak berupa sertifikat yang diterbitkan oleh Kantor Pertanahan Kabupaten / Kota”. Yang dimaksud sertifikat menurut Pasal 1 angka 20 PP No. 24/1997 yaitu: "Sertifikat adalah surat tanda bukti hak sebagaimana dimaksud dalam Pasal 19 ayat (2) huruf c UUPA untuk hak atas tanah, HPL, tanah wakaf, hak milik atas satuan rumah susun dan hak tanggungan yang masing-masing sudah dibukukan dalam buku tanah yang bersangkutan". ${ }^{11}$

${ }^{9}$ Urip Santoso, Pendaftaran dan Peralihan Hak Atas Tanah, Kencana Predana Media Group, Jakarta, 2010, hlm.174.

${ }^{10} \mathrm{Ibid}$.

${ }^{11}$ Peraturan Pemerintah No. 24 Tahun 1997 tentang Pendaftaran Tanah 
Selain peraturan yang telah disebutkan di atas, HPL juga diatur dalam beberapa peraturan diantaranya adalah:

a. PMDN No. 6/1972 tentang Pelimpahan Wewenang Pemberian Hak Atas Tanah. Di sini, HPL ikut diatur oleh Menteri Dalam Negeri terkait pemberian keputusan mengenai permohonan pemberian, perpanjangan / pembaruan, menerima pelepasan, izin pemindahan hak, serta pembatalan hak, hak penguasaan, dan izin membuka tanah yang kewenangannya tidak diberikan kepada gubernur / bupati / walikota / kepala kecamatan. Peraturan ini akhirnya tidak berlaku lagi oleh PMNA / Kepala Badan Pertanahan Nasional No. 3 Tahun 1999 tentang Pelimpahan Kewenangan Pemberian dan Pembatalan Keputusan Pemberian Hak Atas Tanah Negara. Seiring berjalannya waktu, permenag tersebut juga tidak berlaku lagi lantaran adanya Peraturan Kepala Badan Pertanahan Nasional No. 1/2011 tentang Pelimpahan Kewenangan Pemberian Hak Atas Tanah dan Kegiatan Pendaftaran Tanah Tertentu".

b. PMDN No. 5/1973 tentang Ketentuan-Ketentuan Mengenai Tata Cara Pemberian Hak Atas Tanah. Pada peraturan menteri ini, HPL tidak diartikan atau tidak disamakan dengan hak menguasai negara, melainkan sejajar dengan Hak Milik, Hak Guna Usaha, Hak Guna Bangunan, dan Hak Pakai. Selain itu, tata cara pemberian HPL oleh Menteri Dalam Negeri juga diatur di dalam peraturan menteri ini. Pada tahun 1999, peraturan menteri ini tidak berlaku lagi karena digantikan dengan PMNA / Kepala Badan Pertanahan Nasional No. 9/1999”.

c. PMDN No. 5/1974 tentang Ketentuan-ketentuan Mengenai Penyediaan dan Pemberian Tanah untuk Kepentingan Perusahaan ini hanya mengatur HPL untuk kepentingan perumahan (real estate) yang modalnya berasal dari Pemerintah dan / atau Pemerintah Daerah yang diberikan Hak Milik, Hak Guna Bangunan, dan Hak pakai berikut bangunan di atasnya bagi pelaku industri ataupun para pihak yang memerlukan atas usul perusahaan tersebut. 
d. PMDN No.1/1977 tentang Tata Cara Permohonan dan Penyelesaian Pemberian Hak Atas Bagian-bagian Tanah HPL serta Pendaftarannya. Dalam peraturan ini, pemegang HPL berhak memberikan hak lain di atas tanah yang sudah diberikan HPL dengan beberapa hak atas tanah, yaitu Hak Guna Bangunan, Hak Pakai, atau Hak Milik. Setelah dikeluarkannya PMNA/KBPN No. 9/1999, maka PMDN tersebut dinyatakan tidak berlaku lagi.

Ketidakjelasan status HPL tersebut menjadikan subyek pemegang hak kabur pula. Pihak-pihak yang dapat memegang HPL adalah subyek hukum HPL. Subyek hukum merupakan segala hal yan dapat memiliki hak dan kewajiban dari hukum tersebut. Menurut Sudikno Mertokusumo, yang dapat memperoleh hak dan kewajiban adalah manusia. Jadi, manusia oleh hukum diakui sebagai penyandang hak dan kewajiban yang diklasifikasikan menjadi dua macam subyek hukum yaitu:

a. Orang

Setiap Manusia tanpa kecuali, selama hidupnya adalah subjek hukum. Sejak dilahirkan manusia memperoleh hak dan kewajiban. Apabila meninggal, hak dan kewajibannya akan beralih pada ahli warisnya;

b. Badan Hukum

Manusia bukanlah satu-satunya subjek hukum. Dalam lalu lintas hukum diperlukan sesuatu hal lain yang bukan manusia yang menjadi subyek hukum. Di samping orang dikenal juga subyek hukum yang bukan manusia yang disebut badan hukum. Badan hukum adalah organisasi atau kelompok manusia yang mempunyai tujuan tertentu yang dapat menyandang hak dan kewajiban. ${ }^{12}$

Dalam Pasal 67 PMNA No. 9/1999 memberikan kejelasan yang lebih rinci terkait subyek hukum HPL dibandingkan dengan peraturan lain yang mengatur

\footnotetext{
${ }^{12}$ Sudikno Mertokusumo, Mengenal Hukum Suatu Pengantar, Liberty, Yogyakarta, 2002, hlm.6768.
} 
pula HPL, baik yang sudah tidak berlaku maupun yang masih berlaku. Yang semula HPL hanya diberikan kepada departemen, direktorat, jawatan, daerah swatantra (Pemerintah Daerah), perusahaan pembangunan perumahan, dan real estate, Peraturan Menteri ini membuka kemungkinan badan hukum pemerintah lain dapat mempunyai HPL yang ditetapkan oleh pemerintah, namun dengan syarat bahwa tugas pokok dan fungsinya berkaitan dengan pengelolaan tanah.

Sri Hajati menyatakan bahwa HPL tidak dapat diberikan kepada individu atau perorangan, atau badan swasta, badan hukum pemerintah yang tugas pokok dan fungsinya tidak berhubungan dengan pengelolaan tanah. ${ }^{13}$ HPL juga tidak diberikan kepada Warga Negara Indonesia (WNI), Warga Negara Asing (WNA) yang berkedudukan di Indonesia, badan hukum swasta dengan bentuk Perseroan Terbatas (PT), Persekutuan Komanditer (CV), maupun Firma, yayasan, badan hukum asing yang memiliki perwakilan di Indonesia, badan keagamaan maupun sosial, perwakilan dari negara asing, maupun badan internasional. Seperti yang telah dijelaskan sebelumnya, untuk badan hukum, HPL hanya dapat diberikan kepada badan hukum Pemerintah yang tugas pokok dan fungsinya berkaitan dengan pengelolaan tanah. Kesimpulannya adalah tidak semua badan hukum di negara Indonesia dapat memiliki HPL atas Tanah.

Demikian pula terkait masalah kedudukan HPL, hak tersebut menurut pandangan Hukum Tanah Nasional memiliki perbedaan pendapat menurut para ahli. Ada yang mengatakan bahwa HPL adalah termasuk hak menguasai negara atas tanah. Di sisi lain ada yang mengatakan bahwa HPL termasuk hak atas tanah. Menurut pendapat dari Boedi Harsono, HPL dalam "sistematika hak-hak penguasaan atas tanah tidak dimasukkan dalam golongan hak-hak atas tanah. Pemegang HPL memang mempunyai kewenangan untuk menggunakan tanah yang dihaki bagi keperluan usahanya.Tetapi itu bukan tujuan pemberian hak tersebut kepadanya. Tujuan utama adalah bahwa tanah yang bersangkutan disediakan bagi penggunaan oleh pihak-pihak lain yang memerlukan. Sehubungan

\footnotetext{
${ }^{13}$ Sri Hajati, Aspek Yuridis Tanah HPL dan Pemanfaatan oleh Pihak Lain, Makalah Seminar, Fakultas Hukum Universitas Airlangga, Surabaya, 24 Juli 2004, hlm.13.
} 
dengan itu HPL pada hakikatnya bukan hak atas tanah, melainkan merupakan "gempilan" hak menguasai negara. ${ }^{14}$

Sependapat dengan Boedi Harsono, Maria S.W. Sumardjono juga menyatakan bahwa HPL merupakan fungsi / kewenangan publik sebagaimana hak menguasai negara, dan tidak tepat disamakan dengan hak sebagaimana diatur dalam Pasal 16 UUPA karena hak atas tanah hanya menyangkut aspek keperdataan. ${ }^{15}$ Selain Boedi Harsono dan Maria S.W. Sumardjono, Gde Ariyuda berpendapat bahwa pengertian HPL dalam Pasal 1 Angka 3 PMNA/Kepala Badan Pertanahan Nasional No. 9/1999 adalah hak menguasai negara yang kewenangan pelaksanaannya sebagian dilimpahkan kepada pemeganganya, sehingga dengan demikian, HPL adalah bukan hak atas tanah sebagaimana yang dimaksudkan dalam Pasal 16 UUPA. ${ }^{16}$

Terkait masalah kedudukan HPL merupakan hak atas tanah, pendapat ahli yaitu A.P. Parlindungan menyatakan bahwa HPL adalah suatu hak atas tanah yang sama sekali tidak ada istilahnya dalam UUPA, dan khusus hak ini demikian pula luasnya terdapat di luar ketentuan UUPA. ${ }^{17}$ Pendapat lain yang serupa dengan A.P. Parlindungan adalah Effendi Perangin. Menurut Perangin HPL termasuk hak atas tanah yang didaftarkan menurut Peraturan Pemerintah No.10/1961 tentang Pendaftaran Tanah. ${ }^{18}$ Apabila kedudukan HPL terdapat perbedaan pendapat dari segi para ahli, hal tersebut juga terjadi pada peraturan perundang-undangan yang terkait dengan HPL. Adapun Perbedaan Kedudukan HPL Atas Tanah Dalam Hukum Tanah Nasional adalah:

a. HPL merupakan Penguasaan Negara Atas Tanah.

Dalam Pasal 2 ayat (3) Undang-Undang No. 20 Tahun 2000, Pasal 1 Angka 2 Peraturan Pemerintah No. 40 Tahun 1996, Pasal 1 Angka 4 PP No. 24/1997, Pasal 1 Peraturan Pemerintah No. 112 Tahun 2000, Pasal 1 Angka 2 Peraturan

\footnotetext{
${ }^{14}$ Boedi Harsono, Op.Cit., hlm. 277.

${ }^{15}$ Maria S.W. Sumardjono, Tanah dalam Perspektif Ekonomi Sosial dan Budaya, Kompas, Jakarta, 2008, hlm.204.

${ }^{16}$ Gde Ariyuda, Praktik Pemberian Hak Atas Tanah yang Berasal dari Tanah HPL, Makalah Seminar, Fakultas Hukum Universitas Airlangga Surabaya, 24 Juli 2004, hlm. 4.

${ }^{17}$ A.P. Parlindungan, Op.Cit., hlm. 1.

${ }^{18}$ Effendi Perangin, Hukum Agraria Indonesia Dari Sudut Pandang Praktisi Hukum, Rajawali, Jakarta, 1989, hlm. 312.
} 
Pemerintah No. 11 Tahun 2010, Pasal 1 Angka 3 PMNA / Kepala Badan Pertanahan Nasional No. 4 Tahun 1998, Pasal 1 Angka 3 Peraturan Kepala Badan Pertanahan Nasional No. 1/2011, Pasal 1 Angka 3 PMNA / Kepala Badan Pertanahan Nasional No. 9/1999, dan Pasal 1 huruf c Keputusan Menteri Negara Agraria / Kepala Badan Pertanahan Nasional No. 9 Tahun 1997 dinyatakan bahwa HPL adalah hak menguasai negara atas tanah. ${ }^{19}$

b. HPL merupakan bagian dari Hak Atas Tanah

Dalam peraturan perundang-undangan ditemukan bahwa HPL disejajarkan dengan Hak Milik, Hak Guna Usaha, Hak Guna Bangunan, dan Hak Pakai. Berdasarkan Pasal 17 Undang-Undang No. 20 Tahun 2011, rumah susun dapat dibangun di atas tanah hak milik, hak guna bangunan atau hak pakai atas tanah negara dan hak guna bangunan atau hak pakai di atas HPL. Selain itu PP No. 24 Tahun 1997 mengatur lingkup Objek Pendaftaran Tanah meliputi: ${ }^{20}$

1) Bidang-bidang tanah yang dipunyai dengan Hak Milik, Hak Guna Usaha, Hak Guna Bangunan, dan Hak Pakai;

2) Tanah HPL;

3) Tanah wakaf;

4) Hak Milik atas satuan rumah susun;

5) Hak Tanggungan;

6) Tanah negara.

Di antara pendapat para ahli dan peraturan perundang-undangan, masingmasing tidak ada sinkronisasi terkait kedudukan HPL. Menurut Urip Santoso, untuk mendapatkan jawaban mengenai kedudukan HPL dalam Hukum Tanah Nasional dapat dianalisis melalui pengertian, sifat, dan wewenang HPL yang dikaitkan dengan hak menguasai negara atas tanah dan hak atas tanah. ${ }^{21}$

Terjadinya HPL menurut peraturan perundang-undangan terbagi menjadi dua, yaitu karena penegasan konversi dan pemberian hak. Adapun penjelasannya adalah sebagai berikut:

\footnotetext{
${ }^{19}$ Urip Santoso, Op.Cit., hlm. 184.

${ }^{20}$ Ibid.

${ }^{21}$ Ibid., hlm. 183.
} 
a. Penegasan Konversi

Konversi adalah penyesuaian hak-hak atas tanah yang pernah tunduk pada sistem hukum yang lama, yaitu hak-hak atas tanah menurut Burgerlijk Wetboek (BW) dan tanah-tanah yang tunduk pada hukum adatuntuk masuk dalam sistem hak-hak atas tanah menurut UUPA. ${ }^{22}$ Jadi maksudnya adalah Konversi merupakan perubahan hak-hak atas tanah dari Hukum Perdata Barat, Hukum Adat, dan daerah swapraja (sebelum berlakunya UUPA), menjadi hakhak yang disesuaikan menurut UUPA. Dalam UUPA, konversi diatur dalam diktum kedua tentang ketentuan konversi". Mengenai hak atas tanah yang dikonversi adalah antara hak atas tanah terdahulu dengan hak atas tanah yang berlaku saat ini, bukan antara hak penguasaan negara atas tanah dengan hak atas tanah.

Berkaitan dengan HPL yang ada karena Konversi, Menurut Peraturan Menteri Agraria No. 9/1965 menjelaskan bahwa HPL pertama ada setelah berlakunya UUPA adalah berasal dari konversi tanah Hak Penguasaan atau dalam bahas Belanda dinamakan beheer, yaitu tanah yang selain digunakan untuk instansi pemerintah, departemen-departemen, direktorat-direktorat, tanah tersebut dapat diberikan kepada pihak ketiga yang membutuhkan. Menurut Pasal 9 Peraturan Menteri tersebut memerintahkan departemen, direktorat, atau daerah swatantra untuk mendaftarkan tanah konversi tersebut ke Kantor Pertanahan setempat yang bersifat wajib, agar diubah menjadi HPL. HPL tersebut lahir apabila pemegang hak telah mendaftarkan Hak Penguasaan tanah negara itu dan terbitlah Sertifikat HPL sebagai tanda bukti hak. Pendaftaran HPL diatur dalam Peraturan Menteri Agraria No. 1/1966.

b. Pemberian Hak

Selain berasal dari konversi, HPL dapat diperoleh dari pemberian hak yang berasal dari tanah negara. Pasal 1 ayat (8) PMNA / Kepala Badan Pertanahan Nasional No. 9/1999 memaparkan bahwa: "Pemberian hak atas tanah adalah penetapan Pemerintah yang memberikan sesuatu hak atas tanah Negara, termasuk pemberian hak di atas HPL".

${ }^{22}$ A.P. Parlindungan, Konversi Hak-Hak Atas Tanah, Mandar Maju, Bandung, 1990, hlm. 5. 
Asal tanah yang dimohonkan HPL melalui permohonan pemberian hak adalah tanah negara. ${ }^{23}$ Calon pemegang HPL adalah subyek hukum HPL yang tidak mempunyai hak penguasaan atas tanah negara sebelumnya dan berkeinginan mempunyai HPL. Berdasarkan penjabaran di atas, tanah yang menjadi obyek HPL adalah tanah negara. Artinya tidak ada hak individual (hak-hak atas tanah) yang di atasnya. Apabila tanah tersebut terdapat hak atas tanah, maka hak atas tanah sebelumnya harus dilepaskan terlebih dahulu dengan pemberian ganti rugi oleh calon pemegang HPL. Dengan begitu, hak atas tanah yang ada sebelumnya menjadi hapus dan tanah tersebut beralih menjadi tanah penguasaan negara. Barulah setelah tanah itu menjadi hak penguasaan negara, calon pemegang HPL dapat melakukan permohonan hak atas tanah tersebut ke Kantor Pertanahan Kabupaten / Kota setempat.

Pemberian HPL atas tanah tidak terlepas dari kewenangan yang diberikan kepada Pemegang HPL. Dalam berbagai peraturan perundangundangan yaitu, Pasal 2 ayat (3) Undang-Undang No. 20 Tahun 2000, dan Pasal 1 Peraturan Pemerintah No. 112 Tahun 2000 menjelaskan kewenangan pemegang HPL adalah:

1) Merencanakan peruntukan dan penggunaan tanah. Artinya, perencanaan peruntukan dan penggunaan tanah harus disesuaikan dengan Rencana Tata Ruang Wilayah (RTRW) daerah setempat sesuai Peraturan Daerah masing-masing Provinsi dan Kabupaten / Kota.

2) Menggunakan tanah untuk keperluan pelaksanaan tugasnya. Pemegang Hak Pengelolaan berhak menggunakan tanahnya untuk keperluan tugastugasnya, seperti pembangunan perumahan, pembangunan kantor, pembangunan pabrik, ruko, pembangunan kawasan perindustrian dan perdagangan, dan lain sebagainya.

3) Menyerahkan bagian-bagian tanah HPL kepada pihak ketiga dan atau bekerja sama dengan pihak ketiga.

${ }^{23}$ Urip Santoso, Op.Cit., hlm. 196. 
Terkait pemberian kepada pihak ketiga, Pasal 44 UUPA menyatakan bahwa tanah yang dapat disewakan oleh pemegang haknya kepada pihak lain hanyalah Hak Milik, yang dikenal dengan Hak Sewa Untuk Bangunan (HSUB). Hak-hak atas tanah yang dapat diberikan kepada pihak ketiga dan berasal dari HPL adalah:

a. dapat diberikan dalam bentuk hak pakai selama jangka waktu 6 (enam) tahun (Menurut Permenag No. 9/1965);

b. dapat diberikan dalam bentuk Hak Milik, Hak Guna Usaha, Hak Guna Bangunan, atau Hak Pakai untuk tanah HPL yang dikuasai oleh Perusahaan Pembangunan (Menurut Pasal 5 Ayat (7) PMDNNo. 5/1974);

c. dapat diberikan dalam bentuk Hak Guna Bangunan atau Hak Pakai apabila tanah HPL tersebut dikuasai oleh industrial estate (Pasal 6 Ayat (6) PMDNNo. 5/1974).

Terhadap pihak ketiga yang ingin menguasai tanah HPL, terlebih dahulu harus membuat perjanjian penggunaan tanah antara pemegang Hak Pengeolaan dengan pihak ketiga. Sesuai pada Pasal 4 ayat (2) PMNA/Kepala Badan Pertanahan Nasional No. 9/1999 menyatakan bahwa dalam hal tanah yang dimohon merupakan tanah HPL, pemohon harus terlebih dahulu memperoleh penunjukan berupa perjanjian penggunaan tanah dari pemegang HPL.

Apabila telah dibuatnya perjanjian penggunaan tanah antara kedua belah pihak, maka timbulah hubungan hukum antara keduanya. Menurut Maria S.W. Sumardjono, hubungan hukum yang menjadi dasar pemberian hak atas tanah oleh pemegang HPL kepada pihak ketiga dinyatakan dalam Surat Perjanjian Penggunaan Tanah (SPPT). ${ }^{24}$ Jika telah dibuatnya perjanjian penggunaan tanah tersebut, maka timbulah hak dan kewajiban para pihak.

Meskipun antara pemegang HPL dengan pihak ketiga telah membuat perjanjian penggunaan tanah, tanah tersebut belum melahirkan Hak Guna Bangunan atau Hak Pakai atas tanah HPL. Pihak ketiga yang menjadi calon pemegang Hak Guna Bangunan atau Hak Pakai harus mengajukan permohonan pemberian Hak Guna Bangunan atau Hak Pakai atas tanah HPL ke Kepala Kantor

${ }^{24}$ Maria S.W. Sumardjono, Op.Cit., hlm. 29. 
Pertanahan setempat.Pemberian Hak Guna Bangunan atau Hak Pakai di atas tanah HPL memiliki jangka waktu tertentu. Sesuai Peraturan Pemerintah No. 40 Tahun 1996, jangka waktu pemberian Hak Guna Bangunan di atas tanah HPL adalah 30 tahun untuk pertama kali, dan dapat diperpanjang paling lama 20 tahun, serta hak tersebut dapat diperbarui paling lama 30 tahun. Untuk pemberian Hak Pakai di atas tanah HPL, jangka waktunya paling lama 25 tahun untuk pertama kali, dan dapat diperpanjang paling lama 20 tahun, serta hak tersebut dapat diperbarui paling lama 25 tahun. Dalam melakukan perpanjangan, harus mendapat persetujuan dari pemegang HPL.

Selain berwenang menyerahkan HPL kepada pihak ketiga dalam bentuk pemberian Hak Guna Bangunan atau Hak Pakai, pemegang HPL berwenang menyerahkan tanahnya kepada pihak ketiga dengan diberikan Hak Milik, artinya, terlepaslah hubungan hukum antara pemegang HPL dengan pihak ketiga. Penyerahan tanah HPL kepada pihak ketiga untuk diberikan Hak Milik tidak dengan carapembuatan perjanjian penggunaan tanah, melainkan dengan pelepasan atau penyerahan HPL oleh pemegang haknya.

Maksud dari pelepasan atau penyerahan HPL adalah perbuatan melepaskan hubungan hukum antara kedua belah pihak dengan atau tanpa ganti rugi berdasarkan musyawarah mufakat. Dengan pelepasan atau penyerahan HPL kepada pihak ketiga, bukan berarti HPL menjadi beralih, namun HPL menjadi hapus karena telah menjadi Hak Milik atas nama pihak ketiga. Selain itu tanah tersebut dapat beralih kepada ahli waris karena sifatnya Hak Milik adalah turuntemurun dan tidak ada jangka waktu (selama-lamanya). Apabila tanah HPL tersebut dikuasai oleh pemerintah kabupaten/kota, maka pelepasan atau penyerahan tanah HPL tersebut harus mendapatkan persetujuan tertulis terlebih dahulu dari Dewan Perwakilan Rakyat Daerah (DPRD) Kabupaten/Kota karena tanah HPL tersebut merupakan tanah aset (kekayaan) Pemerintah Kabupaten/ Kota. $^{25}$

Penegasan bahwa HPL diberikan oleh negara kepada pemohon, negara sebagai pemegang kekuasaan tertinggi atas tanah, namun kekuasaan negara atas

${ }^{25}$ Urip Santoso, Op.Cit., hlm. 210. 
tanah yang tidak dipunyai dengan sesuatu hak oleh seseorang atau pihak lainnya adalah lebih luas dan penuh, dikaitkan dengan pemberian HPL atas bidang tanah yang telah dikuasai, diduduki atau digarap oleh warga, maka pemberian HPL tersebut adalah tidak sah atau cacat hukum.

\section{PENUTUP}

Negara sebagai pemegang kekuasaan tertinggi atas tanah, kekuasaan tersebut meliputi mengatur dan menyelenggarakan peruntukan, penggunaan, persediaan dan pemeliharaan bumi, air dan ruang angkasa tersebut; menentukan dan mengatur hubungan-hubungan hukum antara orang-orang dengan bumi, air dan ruang angkasa; menentukan dan mengatur hubungan-hubungan hukum antara orang-orang dan perbuatanperbuatan hukum yang mengenai bumi, air dan ruang angkasa.

Atas dasar hak menguasai dari Negara tersebut ditentukan adanya macammacam hak atas permukaan bumi, yang disebut tanah, yang dapat diberikan kepada dan dipunyai oleh orang-orang baik sendiri maupun bersama-sama dengan orang lain serta badan-badan hukum. Kekuasaan Negara atas tanah yang tidak dipunyai dengan sesuatu hak oleh seseorang atau pihak lainnya adalah lebih luas dan penuh.

Keputusan Menteri Negara Agraria/Kepala Badan Pertanahan Nasional menerbitkan Keputusan No. 53/ HPL/BPN/1997 tentang Pemberian HPL atas Nama Pemerintah Kotamadya Daerah Tingkat II Surabaya. Padahal bidang tanah tersebut telah dikuasai, diduduki atau digarap oleh warga cacat hukum. Terjadi maladministrasi, namun karena Badan Pertanahan Nasional tidak lagi mempunyai wewenang membatalkan sertipikat ha katas tanah, untuk itu hendaknya warga masyarakat yang terdampak Keputusan Menteri Negara Agraria/Kepala Badan Pertanahan Nasional menerbitkan Keputusan No. 53/ HPL/BPN/1997 tentang Pemberian HPL Atas Nama Pemerintah Kotamadya Daerah Tingkat II Surabaya mengajukan gugatan pembatalan sertipikat HPL ke Pengadilan Tata Usaha Negara. 


\section{DAFTAR PUSTAKA}

Ariyuda, Gde, Praktik Pemberian Hak Atas Tanah yang Berasal dari Tanah HPL, Makalah Seminar, Fakultas Hukum Universitas Airlangga Surabaya, 24 Juli 2004.

Hajati, Sri, Aspek Yuridis Tanah HPL dan Pemanfaatan oleh Pihak Lain, Makalah Seminar, Fakultas Hukum Universitas Airlangga, Surabaya, 24 Juli 2004,

Harsono, Boedi, Hukum Agraria Indonesia Sejarah Pembentukan Undangundang Pokok Agraria, Isi dan Pelaksanaannya, Djambatan, Jakarta, 1999.

, Hukum Agraria Indonesia, Sejarah Pembentukan Undang-undang Pokok Agraria, Isi dan Pelaksanaannya, Jambatan, Jakarta, 2003

Hukum Agraria Indonesia, Sejarah Pembentukan Undang-undang Pokok Agraria, Isi dan Pelaksanaannya, Djambatan, Edisi Revisi, Jakarta, 2007.

Mertokusumo, Sudikno, Mengenal Hukum Suatu Pengantar, Liberty, Yogyakarta, 2002

Parlindungan, A.P. HPL Menurut Sistem Undang-Undang Pokok Agraria, Mandar Maju, Bandung, 1989.

Parlindungan, A.P. Konversi Hak-Hak Atas Tanah, Mandar Maju, Bandung, 1990

Perangin, Effendi, Hukum Agraria Indonesia Dari Sudut Pandang Praktisi Hukum, Rajawali, Jakarta, 1989

Santoso, Urip, Pendaftaran dan Peralihan Hak Atas Tanah, Kencana Predana Media Group, Jakarta, 2010

Sumardjono, Maria S.W. Kebijakan Pertanahan Antara regulasi dan Implementasi, Kompas, Jakarta, 2001.

Sumardjono, Maria S.W. Tanah dalam Perspektif Ekonomi Sosial dan Budaya, Kompas, Jakarta, 2008.

Wignjodipuro, Surojo, Pengantar dan Asas-asas Hukum Adat, Sumur Bandung, Jakarta, 1982. 


\section{SAPIENTIA ET VIRTUS}

Jurnal Berkala FH UKDC

JI. Dr.Ir. H. Soekarno 201 Surabaya | Tel (031) 5946482 | Fax (031) 5939625

hittp /tukdc ac id//urnal/index.php/SEV. E-mail: fakultas hukum@ukdc ac. id

Surahaya, 01 Juli 2019

Hal : Penerimaan Naskah Publikasi Jurnal

Kepada Yth.

FELIX KURNIAWAN

Terima kasih telah mengirimkan artikel ilmiah untuk diterbitkan pada Jurnal Sapientia et Virtus

(ISSN 2355-343X) dengan judul:

\section{ASPEK HUKUM PEMBERIAN HPL ATAS BIDANG TANAH YANG TELAH DIKUASAI, DIDUDUKI ATAU DIGARAP OLEH WARGA}

Berdasarkan hasil review yang telah dilakukan, artikel tersebut dinyatakan DITERIMA dan telah dipublikasikan di Jurnal Sapientia Et Virtus Volume 4, Nomor 2.

Artikel tersebut telah tersedia secara daring (online) di: http://jurnal.ukdc.ac.id/index.php/SEV/article/view/126.

Demikian informasi ini disampaikan, dan atas perhatiannya diucapkan terima kasih.

Hormat kami,

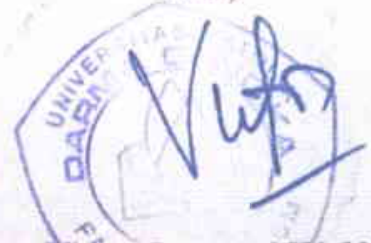

Vietor Imanuel W. Nalle, S.H, M.H.

Edtor Jurnal Sapientia et Virtus

Fakultas Hukum Universitas Katolik Damma Cendika 